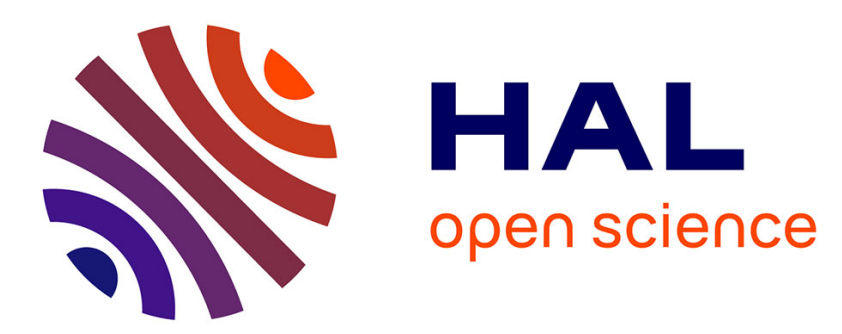

\title{
Estimating and restoring bedload transport through a run-of-river reservoir
}

\author{
T. Depret, H. Piegay, V. Dugué, L. Vaudor, J.B. Faure, Jérôme Le Coz, B. \\ Camenen
}

\section{- To cite this version:}

T. Depret, H. Piegay, V. Dugué, L. Vaudor, J.B. Faure, et al.. Estimating and restoring bedload transport through a run-of-river reservoir. Science of the Total Environment, Elsevier, 2019, 654, pp.1146-1157. 10.1016/j.scitotenv.2018.11.177 . hal-02608072

\section{HAL Id: hal-02608072 \\ https://hal.inrae.fr/hal-02608072}

Submitted on 16 May 2020

HAL is a multi-disciplinary open access archive for the deposit and dissemination of scientific research documents, whether they are published or not. The documents may come from teaching and research institutions in France or abroad, or from public or private research centers.
L'archive ouverte pluridisciplinaire HAL, est destinée au dépôt et à la diffusion de documents scientifiques de niveau recherche, publiés ou non, émanant des établissements d'enseignement et de recherche français ou étrangers, des laboratoires publics ou privés. 


\title{
Estimating and restoring bedload transport through a run-of-river reservoir
}

\author{
Thomas Dépret, ${ }^{\mathrm{a}, \mathrm{b} *}$, Hervé Piégay ${ }^{\mathrm{a}}$, Violaine Dugué ${ }^{\mathrm{c}, \mathrm{d}}$, Lise Vaudor ${ }^{\mathrm{a}}$,
} Jean-Baptiste Faure ${ }^{c}$, Jérôme Le $\mathrm{Coz}^{\mathrm{c}}$, Benoît Camenen ${ }^{\mathrm{c}}$

${ }^{a}$ Université de Lyon, CNRS, UMR 5600 - Environnement-Ville-Société, Site ENS de Lyon, 15 Parvis René Descartes, Lyon 69342, France

${ }^{\mathrm{b}}$ now Laboratoire de Géographie Physique, CNRS UMR8591, 1 Place Aristide Briand, 92195 Meudon, France

c Irstea, UR RiverLy, centre de Lyon-Villeurbanne, 5 Rue de la Doua, CS 20244, F-69625 Villeurbanne Cedex, France

${ }^{\mathrm{d}}$ now Compagnie Nationale du Rhône, 2 rue André Bonin, 69004 Lyon, France

\section{* Corresponding author, e-mail address: thomas.depret@lgp.cnrs.fr}

\section{Abstract}

Weirs or run-of-river dams can disrupt bedload transfer with negative ecological effects downstream due to sediment starvation. The way and the degree to which bedload is trapped is nevertheless not straightforward and few studies have examined this topic. This study focuses on a 13km-long reservoir of the Rhône River, France, created by a diversion dam equipped with bottom gates. Our main objective was to determine the degree of alteration of the bedload transfer downstream and to identify to which extent the implementation of Ecomorphogenic Flow (EmF), defined as environmental flow whose objective is specifically to increase bedload transfer through the reservoir to promote downstream habitat diversity, could increase bed mobility. The results show that the potential for morphological adjustments in the reservoir was already low before dam completion (1968) in response to a substantial decrease in coarse sediment supply, but that this potential was progressively reduced due to the impoundment. However, the bedload transfer continuity has been at least partially maintained since dam completion. According to numerical simulations, only particles smaller than medium gravels $(d<14 \mathrm{~mm})$ could be exported downstream of the dam for relatively rare discharge (50-years return-interval flood). Implementation of EmF could neatly improve the bedload transfer since it would allow to strongly increase the competence: for a 2-years and a 50-years return-interval floods, the maximum particle size exportable downstream is respectively 9 and 4 times larger than for normal functioning of the reservoir operating. 


\section{Keywords}

Environmental flow; Bedload continuity; Flow competence; Process-based restoration; Run-of-river dam; Impoundment

\section{Highlights}

- Partial maintenance of bedload transfer through a run-of-river reservoir of a large gravel-bed river

- Integrated approach combining sediment budgets and hydraulic modelling

- Increase of bed mobility through implementation of Environmental Flows

\section{Introduction}

The effects of large dams on river morphology and sediment transport have been widely studied and are therefore relatively well known. Since they modify the upstream hydraulic condition in the impounded sections by lowering the energy slope, dams interrupt bedload transport and sometimes suspended load, inducing a progressive filling of the reservoirs (Kondolf et al., 2014; Morris et al., 2008). Whereas at their entrance, coarse sediment deposits form a prograding delta with grain size decreasing with downstream distance, reservoirs are mainly filled by fine and more homogenous silty deposits that can be settled by turbidity currents (Kostic and Parker, 2003; Lajczak, 1996; Morris and Fan, 1998; Snyder et al., 2004). Downstream of dams, the effects of flow and sediment regime alteration is highly variable, depending on the pre-dam context (sediment size and supply, competence and capacity of the river, flow regime) and on the intensity and nature of the perturbations (Williams and Wolman, 1984; Brandt, 2000; Petts and Gurnell, 2005, 2013; Schmidt and Wilcock, 2008; Curtis et al., 2010; Dade et al., 2011; Grant, 2012). Most of the time, dams cause a geomorphic simplification (Graf, 2006), generally induced by bed incision, a decrease in lateral mobility and bed armouring (Rollet et al., 2013). Together with the modification of the flow regime, geomorphic simplification results in a loss in aquatic and riparian ecological diversity (Lobrera et al., 2016; Nilsson and Berggren, 2000; Rolls and Bond, 2017; Rosenberg et al., 2000).

Until very recently, less attention has been paid to the impacts of run-of-river dams (Csiki and Rhoads, 2010, 2014; Ibisate et al. 2013), despite their widespread presence. Yet, particularly because of their potential cumulative effects, series of run-of-river dams can also modify hydrological and sediment dynamics, as well as ecological functions (Dessaix et al., 1995; Kibler and Tullos, 2013; Anderson et al., 2015; Fencl et al., 2015). The term "run-of-river dam" still suffers from a lack of a clear definition, and other words such as "weir", "low-head dam", "overflow dam" or "small dam" are usually employed to define similar kinds of structures (Csiki and Rhoads, 2010, 2014; Fencl et al., 2015). Here, we will retain the definition given by Csiki and Rhoads (2010), namely a "structure that extends across the width of a stream or river channel, has no mechanism inhibiting discharge of water 
over the dam, and is of a height that generally does not exceed the elevation of the channel banks upstream - i.e., water stored upstream at base flow is contained within the river channel width of a stream or river channel". Costigan et al. (2016) note that 97\% of dams in the United States are run-ofriver dams. In France, the ROE (Référentiel des Obstacles à l'Ecoulement), a large national database listing most of the transverse engineering structures impeding flow, identifies more than 57,400 weirs (May 2014 inventory), namely 81\% of the total number of dams. Concerning their influence on bedload, two main questions systematically arise. First, how much is the sediment transport altered? Second, in case of partial or total interruption, what solutions could be applied to enhance or restore the sediment transfer through the reservoir? In some countries of the European Union, this concern has been integrated into the national legislative frame following the Water Framework Directive. In France for example, authorities must now guarantee "sufficient transport" maintaining or restoring the morphological and ecological structures and functions of rivers (Malavoi et al., 2011).

All other conditions being equal, the intensity of a run-of-river dam's influence on the morphodynamics and coarse sediment transport in impounded reaches is mainly controlled by the presence or absence of bottom gates. In absence of such gates or when they are maintained closed, and at least in an initial stage, all or most of the bedload can be trapped in the reservoir (Kibler et al., 2011; Pearson and Pizzuto, 2015) and the grain size of coarse deposits tends to show a decreasing downstream pattern (Sindelar et al., 2017). Depending on dam height, bed hydraulic characteristics before impoundment, grain size and sediment yield, bedload transfer can nevertheless be preserved or restored, at least for medium-term periods. For example, Csiki and Rhoads (2014) documented the case of four run-of-river dams showing an absence of a statistically significant difference in the percentage of sand or gravel in the bed material between upstream and downstream portions of dams, indicating no coarse sediment accumulation in the reservoir and a probable preservation of the bedload transfer continuity. Pearson and Pizzuto (2015) demonstrated that partial reservoir filling can be sufficient to reestablish sediment transfer if a gently sloping ramp is formed just upstream of the dam. If the bedload transfer is disrupted too much, and if there are no possibilities to control water level or discharge, dam removal is the only option for restoring continuity (Bednarek, 2001; Magilligan et al., 2016).

The presence of bottom gates should theoretically reduce the dam's influence on bedload, and so should maintain, at least partially, sediment transfer. This is, for example, the case of the Jons dam on the Rhône River (France), where opening the gates for a discharge slightly lower than the annual flood allows the entire bedload to pass (Petit et al., 1996). If needed, the sediment transfer can be enhanced through flushing and/or sluicing operations whose effects can be reinforced using different strategies, implying a modification of the functioning of the plant associated with the dam, or construction of engineering works along the reservoir, such as training walls (Bieri et al., 2012; Bizzi et al., 2015; Isaac and Eldho, 2016; Sindelar et al., 2017). 
When bedload transfer aims at being restored for ecological considerations, water releases can be implemented as part of environmental flows (Poff, 2017; Poff et al., 2017; Poff and Zimmerman, 2010), defined in the Brisbane declaration (2007) as "the quantity, timing, and quality of the water flows required to sustain freshwater and estuarine ecosystems and the human livelihoods and wellbeing that depend on them" (http://www.watercentre.org/news/declaration). If the objective of such operation is specifically to increase bedload transfer to promote downstream habitat diversity, we suggest using the term "Ecomorphogenic Flows" (EmF). An increase in bedload transport is supposed to promote local sediment storage such as bars which should create topographic and grain size variability that will provide a variety of habitats for organisms (Gaeuman, 2012; Yarnell et al., 2006), a higher range of hydraulic patterns and an improved connectivity between benthic and hyporheic compartments. While such process-based restoration is highly attractive, especially because of its expected long-lasting and sustainable effects (Beechie et al., 2010), it can nevertheless be difficult to implement depending on the context because of the frequent need for trade-off with other water uses such as navigation, electricity production and irrigation. An alternative to this solution can be coarse sediment augmentation downstream of dams (Arnaud et al., 2017; Gaeuman, 2012; Rheinheimer and Yarnell, 2017).

The main objectives of this paper are to provide answers to the following questions. How much can a river bed readjust in a run-of river reservoir following dam completion? What are the current conditions of bed-material load entrainment in the reservoir? What is the degree of bedload transfer downstream of the reservoir? Could bedload mobilization be improved for mitigating downstream ecological impacts? What are the consequences of these issues for bedload management and restoration? We focus on a case study, the Bourg-lès-Valence reach (Figure 1), which can serve as a reference frame for the coarse sediment management of most of the other reservoirs of the Rhône River (France) and more broadly of rivers influenced by run-of-river dams and presenting a strong and long-standing bedload deficit.

\section{Study site}

\subsection{Rhône River context}

Coming from the Swiss Alps, the Rhône River flows over $812 \mathrm{~km}$ draining a catchment area of 98,500 km² (512 km long, with 90,500 km² in France, cf. Figure 1; Olivier et al., 2009; Bravard, 2010). The runoff at its outlet accounts for one-sixth of the total runoff into the Mediterranean Sea (Fruget and Dessaix, 2003).

During the second half of the $20^{\text {th }}$ century, the Rhône River underwent an important phase of taming with the construction of 16 artificial canals parallel to the river course (Stroffek et al., 1996;

146 Olivier et al., 2009; Bravard and Gaydou, 2015). These canals were built to convey most of the annual runoff to hydropower plants, improve commercial navigation and increase irrigation (Stroffek et al., 
1996; Olivier et al., 2009; Bravard and Gaydou, 2015). Since then, the discharge in bypassed reaches is residual (until 2014, between 1/3 and 1/322 of the average discharge), except during floods when discharge is higher than the power plants capacity. The Rhône River is thus composed of a quasicontinuous series of reservoirs and bypassed reaches. Located at the upstream end of the bypassed reaches, diversion dams (run-of-river dams with diversion according to the classification of McManamay et al., 2016) are equipped with bottom gates that are opened during high flows, theoretically allowing the transport of coarse sediments. While bedload continuity remains possible, dams have modified the condition of bedload transport through the reservoirs to an unknown extent. Further, bedload could actually be null due to the low frequency for which critical shear stresses are exceeded. The coarse sediment yield has indeed decreased since the second half of the $19^{\text {th }}$ century due to the channelization of the riverbed associated with bank protections downstream of Lyon (lateral dykes, weirs, groynes, cross-beams) (Bravard, 1987; Bravard and Gaydou, 2015; Poinsart, 1992; Poinsart and Salvador, 1993), preventing any sediment supply by lateral erosion. It is also affected by a reduction in sediment supply from the tributaries (Astrade et al., 2011; Bravard, 2002; Bravard et al., 1999; Bravard and Peiry, 1993; Lefort and Chapuis, 2012; Liébault et al., 1999, 2002; Liébault and Piégay, 2002; Rollet et al., 2013; Warner, 2000). Due to channel incision, sediment winnowing and sediment supply control, bedload is very low on most of the river course and the bed is armoured (Cortier and Couvert, 2001). Nevertheless, respective impacts of each main taming phase on bedload transport still need to be quantified and we do not know precisely if the bed is still able to adjust vertically, since this dimension is the only one in which morphological changes can occur. To counter the adverse effects of these two main taming phases, a large restoration project was initiated in the 1990s (Lamouroux et al., 2015) to improve main channel and former channel ecological diversity in bypassed reaches. In a first step the minimal flow was increased and abandoned channels were rejuvenated by dredging. More recently, a new strategy has emerged, more focused on process-based restoration with riprap removal to reactivate bedload transport and shifting riverscape mosaics, raising especially the question of the potential for bedload transfer through impounded reaches.

\subsection{Bourg-lès-Valence reach}

The study reach is located in the middle section of the Rhône River, just upstream of its confluence with the Isère River, one of its most important tributaries (e.g., catchment size : 11,900 km² mean annual flow at the Beaumont-Monteux gauging station: $329 \mathrm{~m}^{3} \mathrm{~s}^{-1}$ ) (Figure 1). In the same way as the whole Rhône river course downstream of Lyon, the Rhône in this section was constricted from the mid-19th century to the first part of the 20th century with engineering works, built in three steps. Dikes in the floodplain were first erected, from 1810 to 1865 . Submersible dykes appeared then from 1862 to 1897 . Finally, transverse structures as groynes and cros-beams were constructed between 1880 and 1908 (source: 1922 bathymetric map). 
The study reach encompasses most of the reservoir of the Bourg-lès-Valence power plant facility 185 and extends over $9.8 \mathrm{~km}$ from kp 90.00 (acronym for kilometric point, which indicates the kilometric 186 distance from Lyon, with negative values upstream and positive downstream), $400 \mathrm{~m}$ upstream of the 187 confluence with the Doux River to $\mathrm{kp} 99.35$, where the dam is located. The mean river width is $306 \mathrm{~m}$ 188 (range, 161-431 m) and the mean annual discharge is $1067 \mathrm{~m}^{3} \mathrm{~s}^{-1}$. It was computed for the 1956-2013 189 period from the daily Rhône discharge at the Valence gauging station just downstream of the Isère confluence from which we subtracted the daily Isère discharge at the Beaumont-Monteux gauging station located just upstream of the confluence). 
Dépret, T., Piégay, H., Dugué, V., Vaudor, L., Noirot, B., Faure, J.-B., Cassel, M., Le Coz, J., Camenen, B. Estimating and restoring bedload transport through a run-of-river reservoir, Science of the Total Environment, 654 (2019) 1146-1157
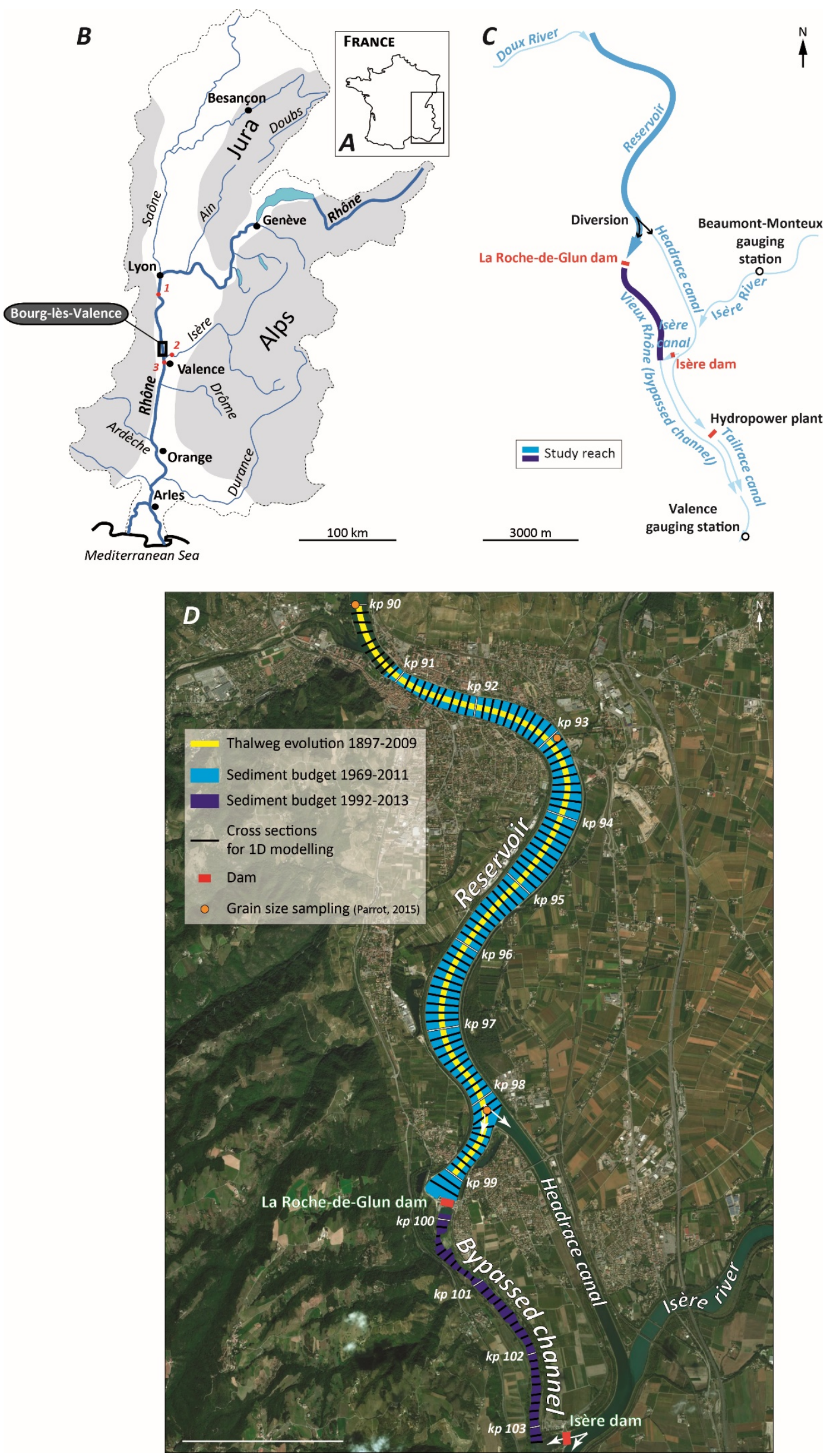
193

194

195

196

197

198

199

200

201

202

203

204

205

206

207

208

209

210

Figure 1 - Location of the study reach in France (A), the Rhône basin (B) (1: Ternay gauging station, 2: Beaumont-Monteux gauging station, 3: Valence gauging station), details of the local context (C), and description of the methodological combination used to characterize bed mobility in the study reservoir $(\mathrm{D}) . \mathrm{Pb}$ affichage echelle à résoudre

The Bourg-lès-Valence power plant facility was put into service in 1968. The impounded reach, which is located along the study reach, stretches from $\mathrm{kp} 86.70$ to $\mathrm{kp} 99.35$ (diversion dam of la Roche-de-Glun; waterfall height $=11 \mathrm{~m}$ for the minimum bypassed discharge, see Figure 1C-D) (Institution interdépartementale des bassins Rhône-Saône, 2003). The artificial canal conveys most of the annual runoff to feed the Bourg-lès-Valence hydropower plant. The bypassed reach is divided into a short upstream section $1 \mathrm{~km}$ long ( $\mathrm{kp}$ 98.30-99.35), corresponding to the downstream end of the reservoir, and an 8.5-km-long downstream section starting from the end of the reservoir (la Roche-deGlun dam) (minimum discharge, 10-20 $\mathrm{m}^{3} \mathrm{~s}^{-1}$ until 31/12/2014, $72 \mathrm{~m}^{3} \mathrm{~s}^{-1}$ thereafter). One should note the presence of the Isère dam (Figure 1C), which is equipped with a dam and allows diversion of waters highly concentrated in suspended sediments from the headrace canal to the bypassed Rhône when a large flood of the Isère River occurs (Camenen et al., 2018). The power plant's capacity is $2,200 \mathrm{~m}^{3} \mathrm{~s}^{-1}$. When the power plant capacity is reached (e.g., $2,200 \mathrm{~m}^{3} \mathrm{~s}^{-1}$ ), the bottom gates of the Roche-de-Glun dam are opened and excess discharge is diverted in the bypassed Rhône.
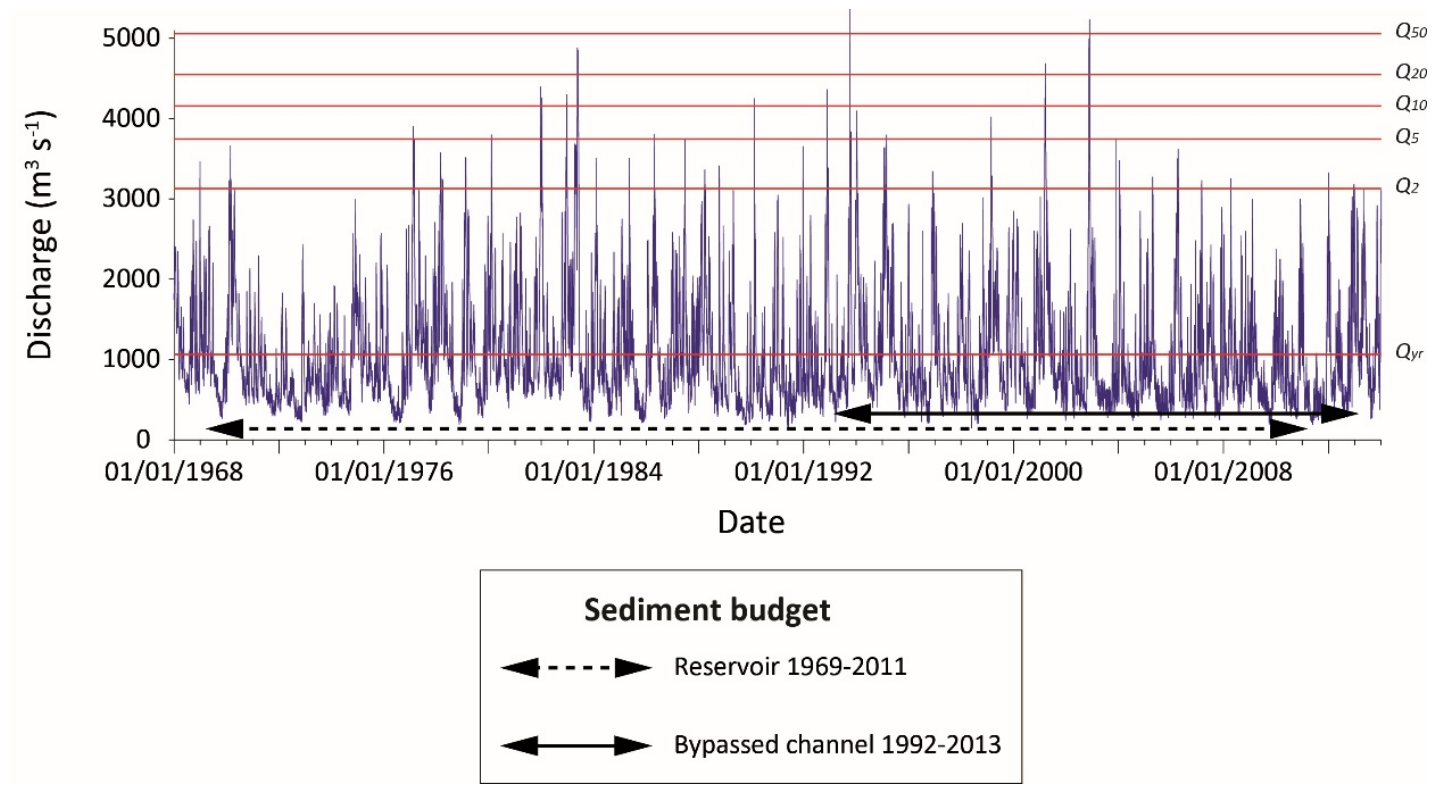

Figure 2 - Daily discharge in the study reach between 1968 and 2013 (corresponding to the daily discharge at the Valence gauging station just downstream of the Isère confluence from which we substrated the daily Isère discharge at the Beaumont-Monteux gauging station just upstream of the confluence, see Figure 1 for location) and sediment budget computation periods . 


\section{Material and Methods}

We adopted a methodological strategy combining geomorphic and hydraulic approaches. First, we characterized the morphological evolution of the study reach since the end of the $19^{\text {th }}$ century by comparing longitudinal profiles of the thalweg. Second, we assessed if the bedload transfer continuity is still at least partially preserved by establishing sediment budgets in the reservoir and in the upstream section of the bypassed reach. Finally, using a 1D hydraulic model, we estimated the current condition of bed mobility by determining the competence of the river along the reservoir as well as the maximum grain size exportable downstream.

\subsection{Bed vertical adjustment following channelization and impoundment}

The adjustment intensity following channelization (which occurred between 1862 and 1908) and impoundment (1968) was determined by comparing longitudinal profiles of the thalweg from different dates every $500 \mathrm{~m}$ (Parrot, 2015) between $\mathrm{kp} 90.00$ and $\mathrm{kp}$ 99.00. The vertical evolution during the first decades following channelization is not documented. Bathymetry was surveyed in 1897 and between 1969 and 2009. For the earliest date, data were extracted from old bathymetric maps on which thalweg elevation is indicated at least every $100 \mathrm{~m}$ and isolines with a resolution ranging from $0.20 \mathrm{~m}$ to $0.50 \mathrm{~m}$ are drawn. If information relative to the accuracy of these survey are unfortunately not available, it seems reasonable to assume that is was lower than their resolution. For the 1969-2009 period, data come from surveys conducted by the CNR.

\subsection{Continuity of sediment transfer downstream the reservoir}

First, we computed a sediment budget in the reservoir between 1969, one year after the commissioning of the hydropower plant, and 2011 (Figure 1 and Figure 2). The study reach encompasses most of the reservoir until the dam (kp 90.90-99.20). Then, we computed a sediment budget for the 1992-2013 period along the upstream section of the bypassed reach, from the dam to the Isere confluence (kp 99.90-103.10). A recent inventory of authorized extractions indicates that gravel was here intensively mined until 1992, with a removal of $1,409,000 \mathrm{~m}^{3}\left(+56,000 \mathrm{~m}^{3}\right.$ possibly mined) (Coeur, 2017). Extractions lowered sharply the bed and created three successive deep in-channel pits (with a maximum deepening of $8 \mathrm{~m}, 11 \mathrm{~m}$ and $4.5 \mathrm{~m}$ from upstream to downstream) in which we assume that most, or even all, of the bedload possibly passing the dam is trapped. It should thus allow to estimate the bedload volume transported from the reservoir since 1992, if any.

\subsubsection{Data}

Bathymetric data were supplied by the CNR. They consist of points along cross sections $100 \mathrm{~m}$ apart (Table 1). The mean point spacing along cross sections varies between 4.1 and $6.5 \mathrm{~m}$. Data were collected using a plumb line, a single-beam or a multi-beam sounder. The maximum measurement error, given by the CNR, is respectively estimated between 0.1 and $0.4 \mathrm{~m}$ depending on date. 
Table 1 - Dates of bathymetric surveys and data characteristics.

\begin{tabular}{cccccc}
\hline $\begin{array}{c}\text { Survey } \\
\text { date }\end{array}$ & Reach & Device & $\begin{array}{c}\text { Measurement } \\
\text { error } \\
(\mathbf{m})\end{array}$ & $\begin{array}{c}\text { Mean number } \\
\text { of points } \\
\text { per cross section }\end{array}$ & $\begin{array}{c}\text { Mean space } \\
\text { between points }\end{array}$ \\
\hline 1969 & Reservoir & Plumb line & 0.4 & 41.7 & 6.5 \\
1992 & Bypassed & Single-beam & 0.2 & 24.1 & 8.4 \\
2011 & Reservoir & Multi-beam & 0.1 & 46.3 & 5.9 \\
2013 & Bypassed & Multi-beam & 0.1 & 49.4 & 4.1 \\
\hline
\end{tabular}

257

258

259

260

261

262

263

264

265

266

267

268

269

270

271

272

273

274

275

276

277

278

279

280

281

282

283

284

\subsubsection{Method}

Sediment budget were obtained applying the method of Guertault et al. (2014) by computing area evolution along each cross section for successive dates and by longitudinally interpolating evolution area considering it as representative of changes that occurred between the mid-distance to the upstream cross section and the mid-distance to the downstream cross section. The budget is associated with a total error, composed of two terms: a measurement error and an interpolation error. It was computed applying the method developed by Arnaud et al. (2017). The measurement error was nevertheless determined as follows and not from repeated measurement of the same points at different dates where no change was assumed, as done for example by Brasington et al. (2000) or Gaeuman (2014): assuming a Gaussian distribution of the measurement error and approximating that the maximum error is equal to three times the standard deviation $(\sigma)$, we estimated the measurement error $\left(\sigma_{\text {meas }}\right)$ as the maximum error divided by 3 .

\subsection{Maximum grain size transported downstream of the reservoir: current functioning and optimization scenarios}

Using a 1D hydraulic model implemented along the Rhône River from the Lake Geneva outlet to the delta (Dugué et al., 2015), we estimated for five different flood discharges the competence along the reservoir as well as the maximal grain size exportable downstream the dam. It was done for the current functioning of the reservoir but also for EmF scenarios aiming at maximizing the bedload transfer downstream of the reservoir (Table 2). For these optimisation scenarios, we increased the velocity in the reservoir by steepening the water slope along its whole course and/or we increased the discharge as much as possible in the bypassed section of the reservoir (Table 1). To this end, several combinations were tested by modifying at least one of the three following parameters that allow controlling the water elevation and the discharge in the different reaches of the facility: the maximum water elevation authorized in the bypassed section of the reservoir, the distribution of the discharge between the bypassed section and the headrace canal and the opening degree of the hydropower plant 
gates. We finally retained two scenarios. The first one is characterised by a lowering of the maximum authorized water surface elevation at $\mathrm{kp} 98.30$ (i.e. at the diversion), from $117.1 \mathrm{~m}$ for normal functioning to $114 \mathrm{~m}$. For a 50 years return-interval flood, it decreases the waterfall height at the la Roche-de-Glun dam from $4.4 \mathrm{~m}$ for normal functioning to $0.7 \mathrm{~m}$. The second scenario i) lowers the water surface elevation at $\mathrm{kp} 99.35$ (i.e. at the Roche-de-Glun dam), from 116.8-117 m for normal functioning to $114 \mathrm{~m}$, ii) derives most of the total discharge in the bypassed channel (keeping a residual flow of $100 \mathrm{~m}^{3} \mathrm{~s}^{-1}$ in the headrace canal), iii) closes the gates of the power plant..

Table 2 - Synthesis of the three scenarios tested with the 1D hydraulic model (Qr $=$ Discharge in the reservoir).

\begin{tabular}{lllll}
\hline \multicolumn{1}{c}{$\begin{array}{c}\text { Reservoir } \\
\text { operating scenario }\end{array}$} & \multicolumn{1}{c}{$\begin{array}{c}\text { Discharge at the } \\
\text { (m) }\end{array}$} & $\begin{array}{c}\text { headrace canal } \\
\text { entrance } \\
\left(\mathbf{m}^{3} \mathbf{s}^{-1}\right)\end{array}$ & $\begin{array}{c}\text { Discharge in the } \\
\text { bypassed channel } \\
\left(\mathbf{m}^{3} \mathbf{s}^{-1}\right)\end{array}$ & $\begin{array}{c}\text { Power plant } \\
\text { gates }\end{array}$ \\
\hline Normal functioning & $\begin{array}{l}117.1 \text { at kp 98.3 } \\
116.8-117 \text { at kp 99.35 }\end{array}$ & 2,000 & Qr $-2,000$ & Opened \\
EmF1 & 114 at kp 98.3 & 2,000 & Qr $-2,000$ & Opened \\
EmF2 & 114 at kp 99.35 & 100 & Qr -100 & Closed \\
\hline
\end{tabular}

\subsubsection{Modelling parameters and simulated discharges}

Running in "steady state" mode, the model was built with topo-bathymetric cross sections $100 \mathrm{~m}$ apart acquired by the CNR from 2004 to 2007. Inputs of tributaries were taken into account by assigning them a constant discharge equal to their mean annual discharge (Doux $=8.6 \mathrm{~m}^{3} \mathrm{~s}^{-1}$; Isère $=$ $329 \mathrm{~m}^{3} \mathrm{~s}^{-1}$ ). The five simulated discharge values were chosen within a range from frequent to rare floods. They correspond to a return-interval (RI) at the Ternay gauging station equal to $2\left(3,200 \mathrm{~m}^{3} \mathrm{~s}^{-}\right.$ $\left.{ }^{1}\right), 5\left(3,900 \mathrm{~m}^{3} \mathrm{~s}^{-1}\right), 10\left(4,300 \mathrm{~m}^{3} \mathrm{~s}^{-1}\right), 20\left(4,700 \mathrm{~m}^{3} \mathrm{~s}^{-1}\right)$ and $50\left(5,200 \mathrm{~m}^{3} \mathrm{~s}^{-1}\right)$ years $\left(Q_{2}, Q_{5}, Q_{10}, Q_{20}\right.$ and $Q_{50}$ respectively). The model predicts surface elevation and section-averaged velocity from which were computed local shear stress and competence at each node of each of the cross sections of the model.

\subsubsection{Competence along the reservoir}

For each simulated discharge and for each node of the model along each cross section, we determined the maximum sediment size that can be mobilized. In absence of any information regarding the bed state and structure, we provided two estimations of the competence, obtained with a critical Shields number of 0.03 and 0.06 . The first one corresponds to a loose structure of the bed 
surface, theoretically characterizing a high mobilization frequency of the bed material. The second one corresponds to a high degree of bed compaction, theoretically characterizing a low mobilization frequency of the bed material. The computation steps were the following.

We first computed the section-averaged total shear stress from the 1D model:

$$
\tau=\rho_{w} g R_{h} J \quad \text { Eq. } 4
$$

where $\rho_{w}$ is the water density $\left(1000 \mathrm{~kg} \mathrm{~m}^{-3}\right), g$ is the gravitational acceleration in $\mathrm{m} \mathrm{s}^{-2}, R_{h}$ is the hydraulic radius in $\mathrm{m}$, and $J$ is the energy slope in $\mathrm{m} \mathrm{m}^{-1}$.

The section-averaged effective bed shear stress was then computed from the Meyer-Peter and Müller equation (1948):

$$
\tau^{\prime \prime}=\tau\left(\frac{K}{K_{S}}\right)^{3 / 2} \quad \text { Eq. } 5
$$

where $K$ is the total Strickler coefficient in $\mathrm{m}^{1 / 3} \mathrm{~s}^{-1}$, and $K_{S}$ the skin Strickler coefficient (grain resistance) in $\mathrm{m}^{1 / 3} \mathrm{~s}^{-1}$ was computed from the following equation:

$$
K_{S}=\frac{26}{D_{90}^{1 / 6}} \quad \text { Eq. } 6
$$

where $D_{90}$ is the size of bed material in millimetres for which $90 \%$ of the number of sediment clasts have a smaller size.

Then, we estimated for each node $i$ of the model the local effective bed shear stress assuming a simple bed shear stress distribution based on the water depth, and assuming a homogeneous roughness throughout the river section (Camenen et al., 2011):

$$
\tau_{i}^{\prime \prime}=\frac{H_{i}}{H} \tau^{\prime \prime} \quad \text { Eq. } 7
$$

where $H_{i}$ is the water height in metres at node $I$ of the cross section, and $H$ the section-averaged water depth.

The competence at each node $i$ was finally determined as follows:

$$
D_{\max (i)}=\frac{\tau_{i}^{\prime \prime}}{g \theta_{c i}\left(\rho_{s}-\rho_{w}\right)} \quad \text { Eq. } 8
$$

where $D_{\max (i)}$ is the competence in $i$, in metres, $\theta_{c i}$ is the critical Shields number and $\rho_{s}$ is the sediment density $\left(2650 \mathrm{~kg} \mathrm{~m}^{-3}\right)$.

Surface $90^{\text {th }}$ grain size percentile $\left(D_{90}\right)$ used in equation (6) was obtained from three volumetric samples taken in 2012 along the reservoir by Parrot (2015). Because grain size remains unknown 
between samples (see Figure 1 for location of the samples), we had to use an estimate on most of cross sections. Two values were computed for each cross section. The first one (hereafter G1) was obtained by the linear interpolation between two consecutive samplings. For the second one (hereafter G2), the grain size at the location of each sample was used on a distance equal to half the distance to the next or the following sample.

\section{Results}

\subsection{Bed readjustment following channelization and impoundment}

The comparison of the thalweg elevation from 1897 to 2009 clearly shows that most of the geomorphic changes along the study reach occurred following the first taming phase of the Rhône River (1862-1908), characterized by the channelization and the disconnection of its multi-thread bed channels (Figure 3). The incision induced by the channelization is probably underestimated since the first decades following it are not documented. Between 1897 and 1969, a large and widespread incision occurred, with a mean value of $-1.67 \mathrm{~m}(\sigma=0.95 \mathrm{~m})$, equivalent to $-0.021 \mathrm{~m} \mathrm{y}^{-1}$. From 1969 to 2009 , the bed stabilized downstream of $\mathrm{kp} 94.00$, with a mean vertical evolution of $-0.066 \mathrm{~m}$ ( $\sigma=$ $0.14 \mathrm{~m}$ ), equivalent to $-0.0005 \mathrm{~m} \mathrm{y}^{-1}$. Along this section, the incision rate is 33 times lower than that of the 1897-1969 period. Upstream of $\mathrm{kp} 92.50$, incision continued with a mean value of $-1.64 \mathrm{~m}(\sigma=$ $1.1 \mathrm{~m})$, equivalent to $-0.042 \mathrm{~m} \mathrm{y}^{-1}$. The incision occurred mainly before 1986 . The section between $\mathrm{kp}$ 92.50 and $\mathrm{kp} 93.50$ underwent aggradation, very likely resulting from sediment reinjections (silt and/or sand) that occurred from 1984 to 2009 (five campaigns in 1984, 1997, 2000, 2001 and 2009).

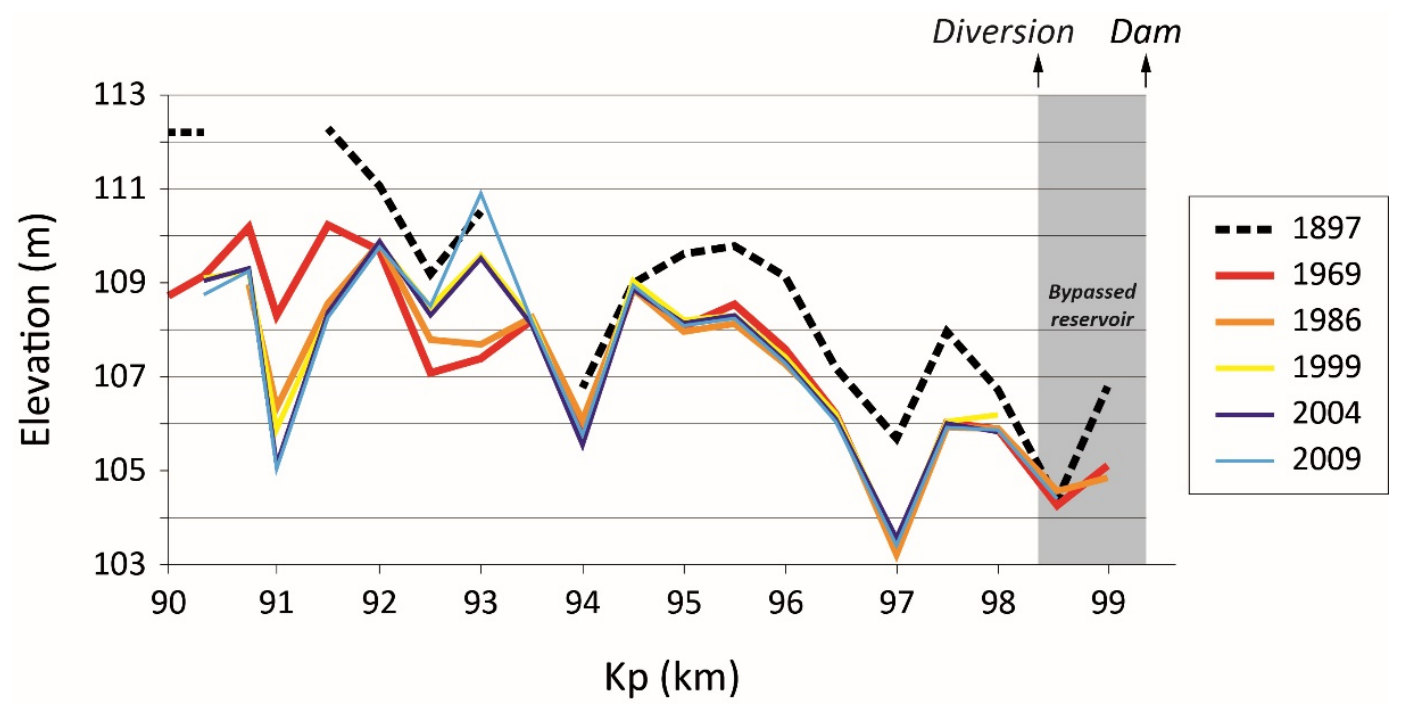

Figure 3 - Thalweg elevation every $500 \mathrm{~m}$ along the reservoir from 1897 to 2009 . $\mathrm{Pb}$ affichage ligne à résoudre 


\subsection{Bedload transfer downstream of the reservoir}

\subsubsection{Sediment budget in the whole reservoir since dam completion}

The sediment budget for the whole reservoir since dam completion is positive $\left(6,500 \mathrm{~m}^{3} \mathrm{y}^{-1}( \pm\right.$ 800)), indicating that the bedload continuity could have been strongly, even totally, interrupted by the dam (Figure 4). Nevertheless, a large part of this deposited material is composed of fine sediments stored in the bypassed section of the reservoir (silt and sand) (Institution interdépartementale des bassins Rhône-Saône, 2003), which must not be taken into account in our budget. Deposition of a part of the suspended load can be explained by the fact that in the bypassed section of the reservoir i) the water slope strongly decreases (for a $Q_{2}, 0.19 \%$ upstream of the diversion, $0.017 \%$ downstream, i.e. a 11.2-fold decrease; for a $Q_{50}, 0.36 \%$ upstream of the diversion, $0.26 \%$ downstream, i.e. a 1.4 -fold decrease), ii) the bed in the downstream $500 \mathrm{~m}$ of the section undergoes a significant enlargement (twice that of upstream) with the bed $2.9 \mathrm{~m}$ wider than the dam, iii) the dam is located on the left side of flow with the eddy in the right half of the channel, contrary to the dam, and fine particle siltation. By excluding these fine sediment deposits, the budget for the entire reservoir would be negative with a value of $800 \mathrm{~m}^{3} \mathrm{y}^{-1}( \pm 300)$. Furthermore, because of dredging and sediment reinjection operations carried out at the end of the study period, a last modification must be applied to the budget by removing the corresponding volumes. In 2005, 29,000 $\mathrm{m}^{3}$ were dredged in the center of the channel from $\mathrm{kp} 92.60$ to $\mathrm{kp}$ 93.00. Since then, no deposit was observed in this area. In 2009, 37,500 $\mathrm{m}^{3}$ of sandy material were reinjected along the outer bank between $\mathrm{kp} 92.50$ and $\mathrm{kp} \mathrm{93.50.} \mathrm{At} \mathrm{the} \mathrm{time} \mathrm{of} \mathrm{the}$ 2011 bathymetric survey, this stock was still in place. Once this taken in consideration, the budget amounts to $-1,000 \mathrm{~m}^{3} \mathrm{y}^{-1}( \pm 300)$. It induces thus that bedload transfer continuity from the reservoir to the bypassed channel is currently still at least partially preserved.

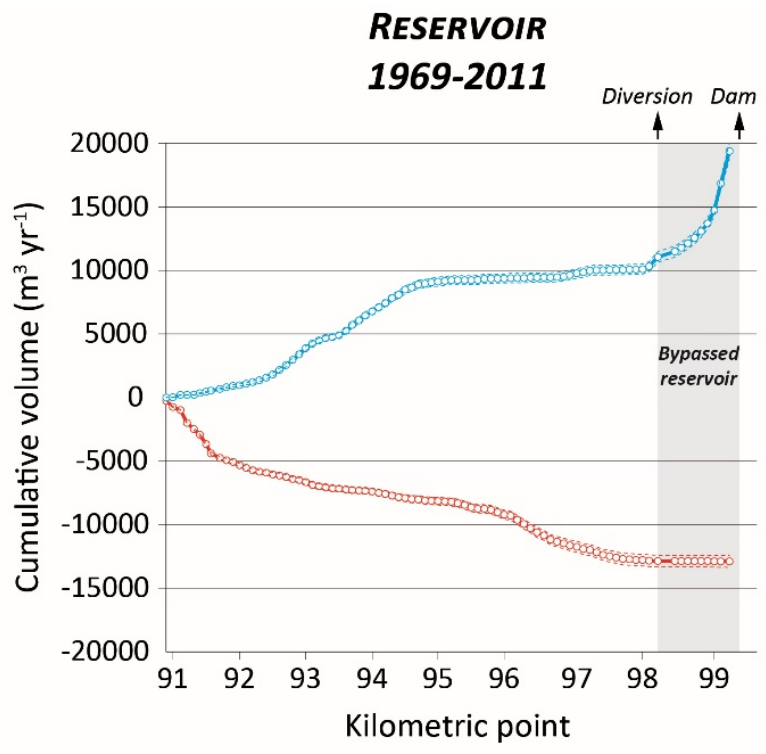

BYPASSED CHANNEL 1992-2013

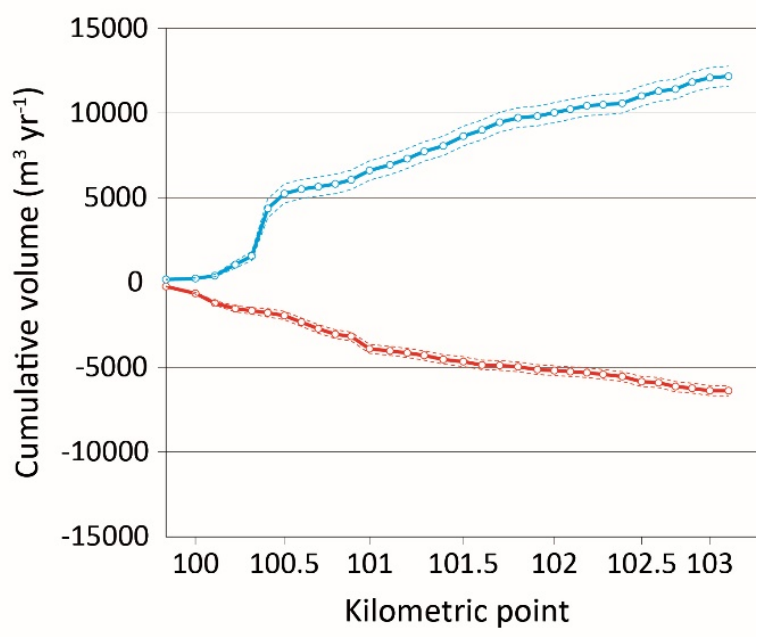


399

400

401

402

403

404

405

406

407

Figure 4 - Net changes in cumulative aggraded and degraded volumes in a downstream direction over time. $\mathrm{Pb}$ affichage ligne à résoudre

Except for the bypassed section of the reservoir mentioned above, intensity of morphological changes decreased downstream, reflecting the increasing influence of the dam (Figure 4). An important part of the degradation took place upstream of $\mathrm{kp} 92.00$. It was then quite low and regular until kp 94.50, from where it became almost null. Most of aggradation occurred upstream of kp 94.70, from which it became very low until the diversion.
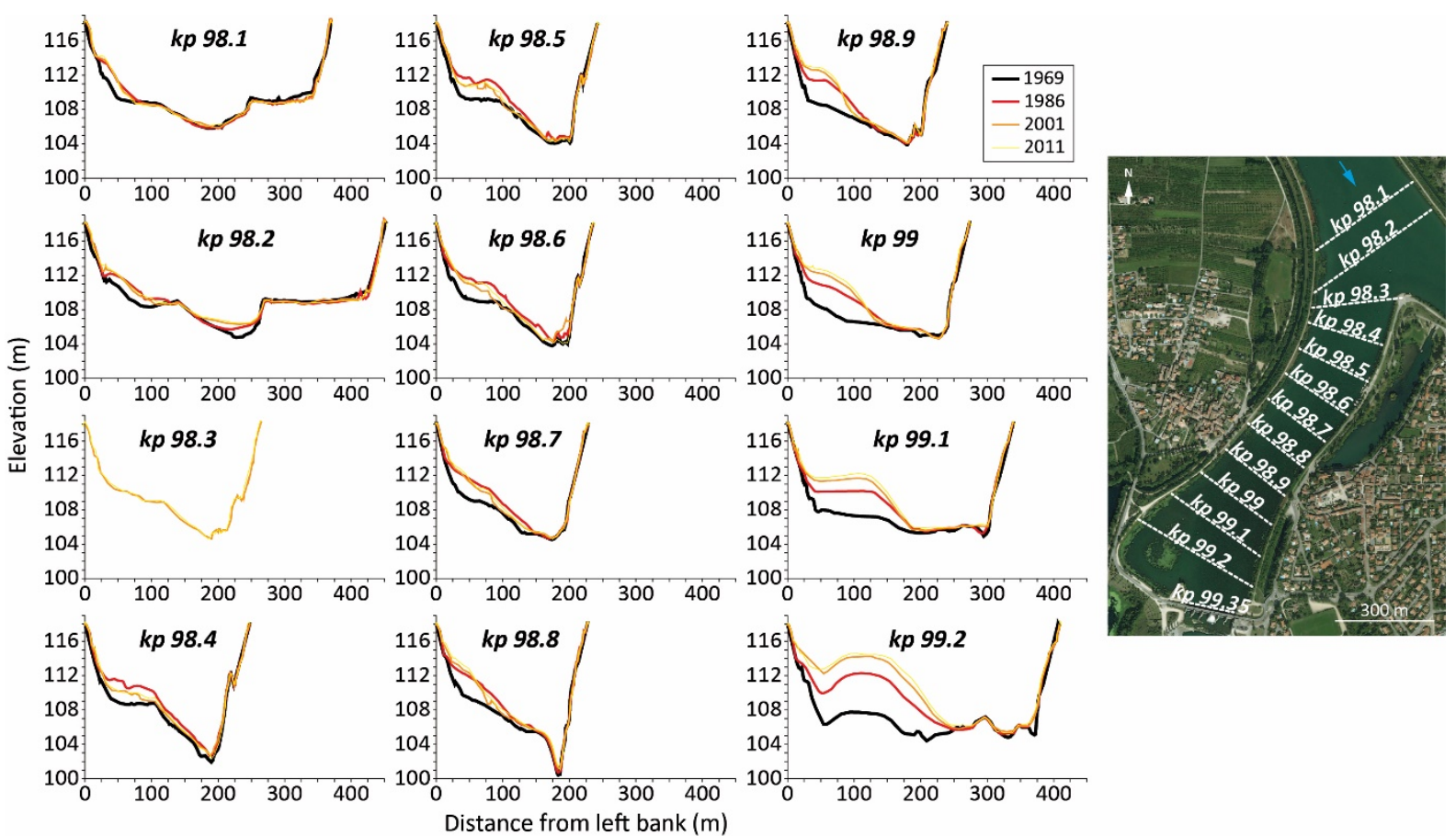

408

409

410

411

412

413

414

415

416

417

418

Figure 5 - Insight of morphological evolution of the reservoir in its downstream bypassed section.

\subsubsection{Sediment budget in the bypassed reach since 1992}

More evidence of the preservation of the bedload transfer continuity is given by the morphological evolution downstream of the dam, along the upstream section of the bypassed channel (from the dam to the confluence with the Isère canal). Here the sediment budget between 1992 and 2013 is positive, with a value of 5,800 $\mathrm{m}^{3} \mathrm{y}^{-1}( \pm 600)$ (Figure 4 and Figure 6). It means that at least such volume were transported each year from the reservoir for this period. An important part of these sediments were deposited along the short upstream pit (kp 100.30-100.60) (Figure 4 and Figure 6). 

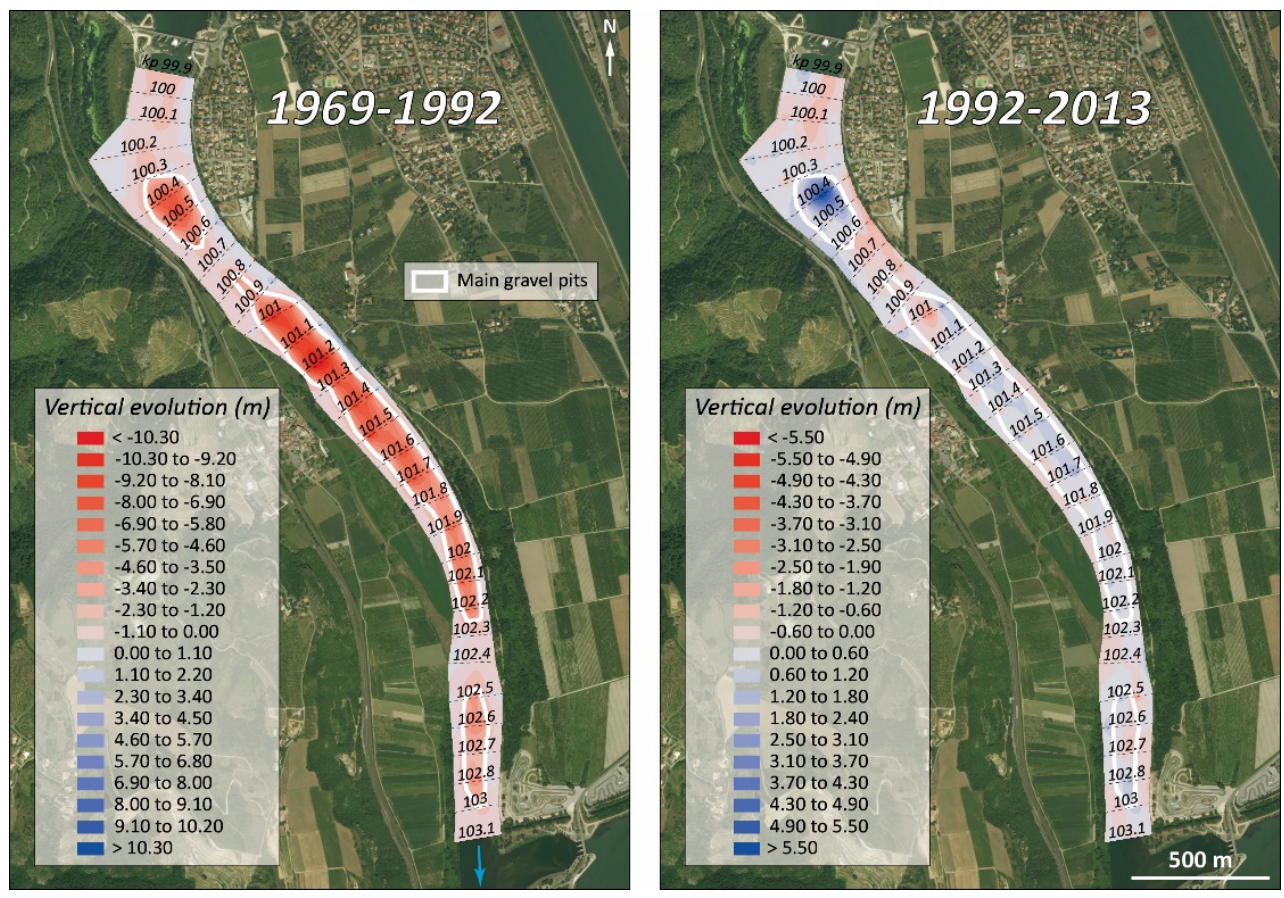

Figure 6 - Morphological evolution of the bypassed section downstream of the dam and upstream of the Isère confluence.

422

423

424

425

426

427

428

429

430

431

432

433

\subsubsection{Maximum grain size exportable from the reservoir}

\section{Current functioning}

For the whole reservoir length, and whatever the simulated discharge or the grain size considered, the maximum competence along each cross section decreases downstream, showing the clear longitudinal influence of the dam on bedload transport (Figure 7). Furthermore, the lowest value of the maximal competence is systematically located at $\mathrm{kp} 99.10$. For a $Q_{2}$, only very fine gravels (according to classification of Blott and Pye, 2001), at best, could be exported from the reservoir (2 $\mathrm{mm}$ at $\mathrm{kp}$ 99.10 for a critical Shields number of 0.03 and for grain size G2) (Figure 7). For a $Q_{50}$, the size increases to $14 \mathrm{~mm}$, which belongs to medium gravel class (kp 99.10 for a critical Shields number of 0.03 and for grain size $G 2$ ). 
GRAIN SIZE 1
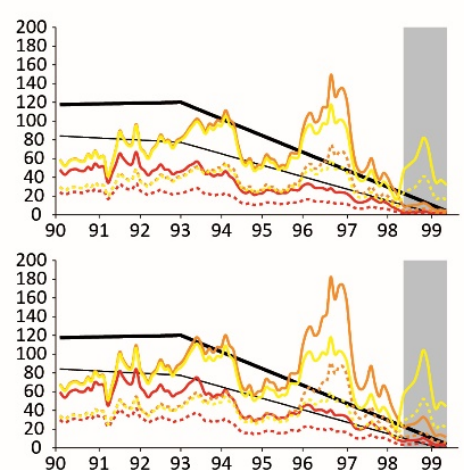

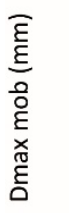
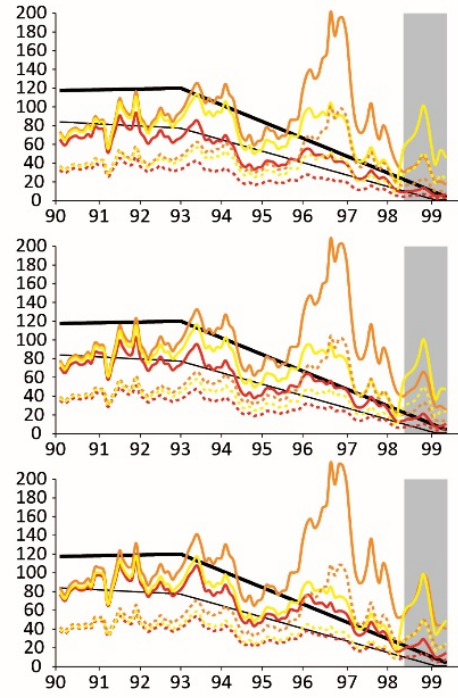

$\mathrm{Kp}(\mathrm{km})$
GRAIN SIZE 2
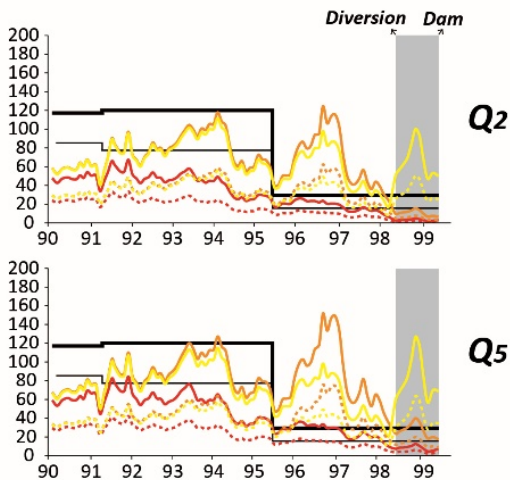

Q5

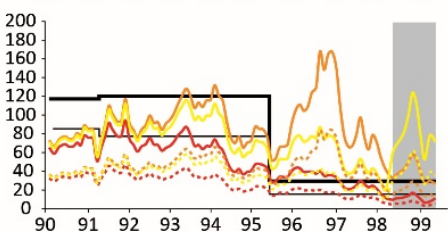

Q10

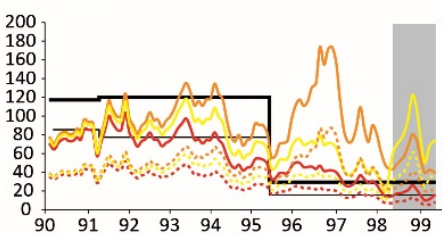

Q20

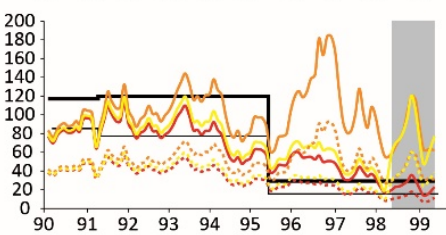

Q50

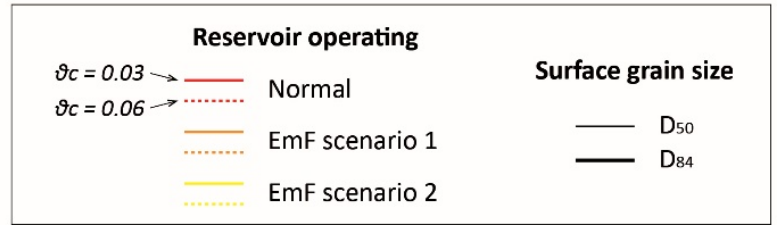

Figure 7 - Longitudinal distribution of the maximum competence for the different GSD and discharges.

\section{EmF conditions}

The effect of EmF is evident since the trend towards a downstream decrease of the competence observed in conditions of normal functioning tends to ease, even to disappear, at least up to $\mathrm{kp} 97.00$ (Figure 7). The attenuation of the trend is stronger for scenario 1 than for scenario 2 (Figure 7). For scenario 1, the stronger the discharge is, the stronger the attenuation is. Conversely, for scenario 2, the attenuation decreases when the discharge increases.

Upstream of the diversion, the best gain in maximum competence compared to normal functioning is obtained for scenario 1. Downstream of the diversion, scenario 2 would be the most efficient for all the simulated discharges except $Q_{50}$, for which the maximum competence is slightly higher for scenario 1 (Figure 7 and Figure 8). Moreover, the difference along this section between both scenarios 
is little by little reduced when the discharge increases: while for scenario 1 the competence rises systematically, for scenario 2 it reaches a maximum for a $Q_{5}$ and then drops slightly (Figure 7 and Figure 8). Furthermore, the maximum competence for scenario 1 at $Q_{50}$ and scenario 2 at $Q_{5}$ are

451

452

453

454

455

456

457

458

459

460

461

462 almost the same.

For scenario 1, the lowest value of the maximal competence in the whole reservoir is located at $\mathrm{kp}$ 99.30 whatever the grain size, except for a $Q_{50}$ with grain size $G 2$ where it is located at kp 98.20 , just upstream the diversion (Figure 7). Furthermore, it increases with discharge. For scenario 2, the lowest value of the maximal competence is systematically located at kp 98.20 (Figure 7). It increases until $Q_{5}$ and then drops very slightly or remains almost constant.

Until a $Q_{5}$, the maximal sediment size that could be exported from the reservoir is obtained with scenario 2 (Figure 7). For a $Q_{2}$, it is equal to $18 \mathrm{~mm}$ (kp 98.20 for a critical Shields number of 0.03 and for grain size G2), representing a nine fold increase compared to the normal functioning (2 mm). From $Q_{10}$, the maximal sediment size that could be exported from the reservoir is obtained with scenario 1 (Figure 7). For a $Q_{50}$, it is equal to $56 \mathrm{~mm}$ at the best (kp 98.20 for a critical Shields number of 0.03 and for grain size G2), which is a fourfold increase compared to the normal functioning (14 mm).

$$
\vartheta_{c}=0.03
$$

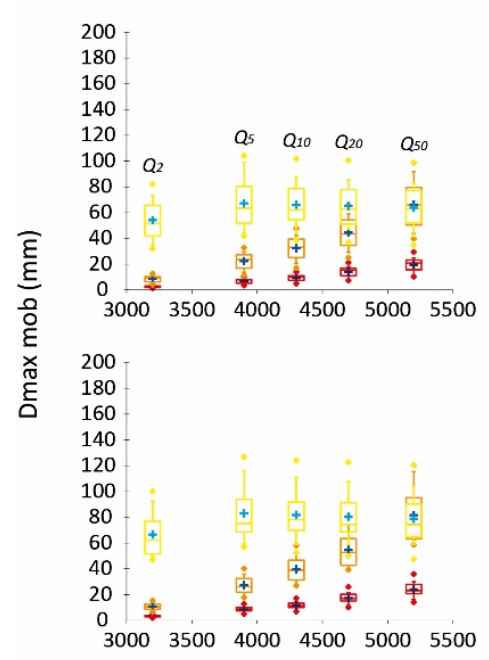

Discharge $\left(\mathrm{m}^{3} \mathrm{~s}^{-1}\right)$

$$
\vartheta_{c}=0.06
$$

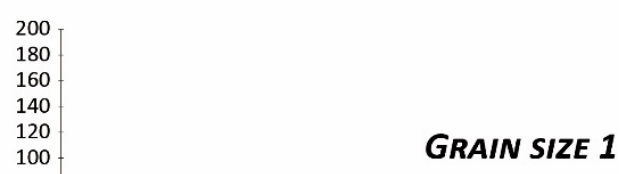

GRAIN SIZE 2

\section{Discussion}

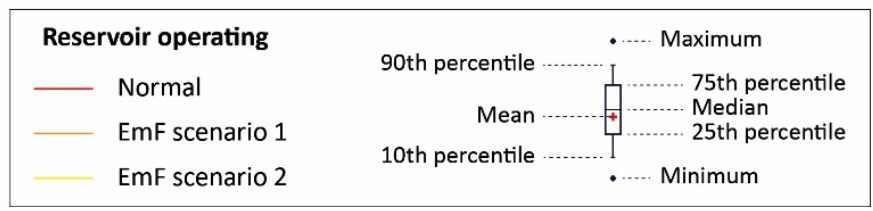

Figure 8 - Box plots of the maximum competence for each of the 11 cross sections located along the bypassed section of the reservoir depending on the choice of the Shields parameter and GSD.

\subsection{Bedload transfer in the reservoir}


The slight modifications that have occurred since the dam construction in 1968 (Figure 3) indicate that the bed was almost totally adjusted to the conditions imposed by its previous channelization and by the bedload supply decrease from tributaries and/or that the impoundment has inhibited the possibilities for further adjustment. If the second factor played a role, we should expect a decrease through time in the intensity of geomorphic changes in case of similar flood intensity and duration. The comparison of degraded volumes between the two periods dominated by channel degradation since 1969 (1969-1986 and 1999-2004) shows such a decrease despite comparable hydrological conditions: for 1969-1986 and 1999-2004, there were respectively 15 and 10 days with discharge higher than the 10-year RI discharge, which is the limit below which no significant changes in the reservoir, especially degradation, could occur; and for each of both periods, one flood with a RI at least equal to 35 years and at least one flood with a 10-year RI were counted (Dépret et al., 2018). Furthermore, while degraded volumes for 1969-1986 were distributed quite linearly along the reservoir, those for 1999-2004 diminished more and more downstream (Dépret et al., 2018). This indicates that the study reach had still some potential for morphological changes at the time of dam completion, even if most of the readjustments following channelization were probably already realized, and that such potential was progressively reduced due to the impoundment.

Sediment budget downstream of the dam since 1992 indicates a bedload volume coming from the reservoir at least equal to $5,800 \mathrm{~m}^{3} \mathrm{y}^{-1}( \pm 600)$. This value is 3.6 time higher than that given by Cortier and Couvert (2001) $\left(1,600 \mathrm{~m}^{3} \mathrm{y}^{-1}\right)$ and 19.7 times lower than their estimation of the annual bedload before impoundment and channelization $\left(114,000 \mathrm{~m}^{3}\right)$. The situation could be greatly improved by implementations of EmF since compared to a normal functioning of reservoir operating, the maximum grain size that could be exported from the impoundment would increase from $2 \mathrm{~cm}$ to $18 \mathrm{~cm}$ for a $Q_{2}$ and from $14 \mathrm{~cm}$ to $56 \mathrm{~cm}$ for a $Q_{50}$. dams

On some of the bypassed reaches of the Rhône River, riprap removal, implying an increase of the sediment supply to the river (Bravard and Gaydou, 2015), has been recently designed. The main goals of these process-based restoration actions are to reactivate bedload transport and promote a shifting riverscape mosaic to improve aquatic and riparian habitats. It raises the operational and scientific questions of the degree of bedload transfer through a bypassed reach to its immediate downstream reservoir, and then to the next bypassed reach. This will condition the spatial scale at which the management of these sediment reinjections should be designed.

The present study shows that according to the most optimistic estimations, and in the absence of EmF, the maximum grain size that could be exported from the reservoir would be smaller than coarse gravels (according to the classification of Blott and Pye, 2001). It corresponds at the best to very fine gravels (2 mm) for a $Q_{2}$ and to medium gravels for a $Q_{50}(14 \mathrm{~mm})$. In case of similar competence in 
other reservoirs, it means that for the coarse fraction of the bedload, each Rhône River reach composed of the succession of a bypassed section and its downstream reservoir should be considered as almost independent of the surrounding ones. Depending on the grain size, bedload management should therefore be considered at different spatial scales: very schematically, the reach scale for sizes from fine gravels to boulders and the scale of the river corridor for very fine gravels and coarse sands. Anticipating what could become the reinjected sediments therefore requires determining their grain size as well as the longitudinal gradient of the competence from the restored bypassed reach to the dam of the downstream reservoir.

So that habitat improvement can be beneficial at the largest spatial and temporal scales, promotion of re-erosion or sediment augmentation must be done ideally on long bypassed reaches, with injection in their upstream section. Nevertheless, because a large part of the bedload, if not all of it, should not pass reservoirs, it could have potential future counter-effects that need to be considered (mainly limitation for navigation and flood hazard aggravation). To make the existing human constraints and the maximization of ecological benefits compatible, process-based solutions can then be implemented jointly with gardening.

A more complex and elaborate way to manage bedload and to increase sediment transfer from restored bypassed reaches would be the implementation of EmF using different configurations depending on the discharge and the longitudinal location of dams in bypassed sections. For dams located at diversions, and whatever the discharge, EmF similar to scenario 1 presented here (no modification of the discharge distribution between the bypassed channel and the headrace canal) should be preferred. For dams located downstream of the diversion, as for our study case, scenario 2 (almost no diversion of discharge in the headrace canal) seems more appropriate for relatively frequent discharges (up to a maximum $Q_{5} Q_{10}$ ). This strategy should obviously be adjusted according to the maximum grain size for which restoration of the continuity is planned. Broadly, these lessons regarding the principles of bedload management learned from the present case study could be generalized to similar rivers influenced by run-of-river dams presenting a strong and long-standing bedload deficit and for which sediment replenishment is carried out.

\section{Conclusion}

This study aimed at estimating the potential for morphological adjustment of a run-of-river dam impoundment, in which sediment augmentation was carried out, and for bedload transfer downstream. Most of the geomorphic changes occurred before dam completion (1969) due to a decrease in coarse sediment supply that occurred during the preceding 100 years because of channelization of the river and less sediment delivery from tributaries. Since the reservoir's creation, changes are minor but the bedload transfer is still maintained. Nevertheless, only particles up to medium-coarse gravels, at best, can be exported downstream of the dam (2-3 $\mathrm{mm}$ for a $Q_{2}$ and 14-23 $\mathrm{mm}$ for a $Q_{50}$ ), which is less than 
the bed $D_{50}$ on most of the reservoir. Implementation of Ecomorphogenic Flows, here defined as environmental flows whose objective is specifically to increase bedload transfer through the reservoir to promote downstream habitat diversity, could improve the situation since the maximum grain size exportable from the reservoir would increase strongly (a ninefold increase for a $Q_{2}$, and around a fourfold increase for discharges from a $Q_{5}$ to a $Q_{50}$ ).

Beyond the imperative need for trade-offs with other water uses if such a measure were implemented, bedload management must be considered at the scale of the entire river corridor in order to precisely localize and quantify the possible sources of sediment supply as well the conditions of bedload transfer (competence and capacity). This characterization of the longitudinal bedload patterns, as developed in Vazquez-Tarrio et al. (2018), can identify where a coarse sediment reinjection (by gravel augmentation or by promoting lateral erosion through riprap removal) could be the most sustainable and thus the most efficient. Finally, the use of an integrated and interdisciplinary methodological approach (sediment budget, 1D model, surface-subsurface grain-size determination) appears especially relevant since it increases the robustness of the results and potentially reduces uncertainty.

\section{Acknowledgments}

This study was conducted within the Rhône Sediment Observatory (OSR), a multi-partner research program funded through the Plan Rhône by the European Regional Development Fund (ERDF), Agence de l'eau RMC, CNR, EDF and three regional councils (Auvergne-Rhône-Alpes, PACA and Occitanie).

\section{References}

Anderson, D., Moggridge, H., Warren, P., Shucksmith, J., 2015. The impacts of 'run-of-river' hydropower on the physical and ecological condition of rivers. Water Environ. J. 29, 268-276.

Arnaud, F., Piégay, H., Béal, D., Collery, P., Vaudor, L., Rollet, A.J., 2017. Monitoring gravel augmentation in a large regulated river and implications for process-based restoration. Earth Surf. Process. Landforms 42 (13), 2147-2166.

Astrade, L., Jacob-Rousseau, N., Bravard, J.P., Allignol, F., Simac, L., 2011. Detailed chronology of mid-altitude fluvial system response to changing climate and societies at the end of the Little Ice Age (Southwestern Alps and Cévennes, France). Geomorphology 133, 100-116.

Beechie, T.J., Sear, D.A., Olden, J.D., Pess, G.R., Buffington, J.M., Moir, H., Roni, P., Pollock, M.M., 2010. Process-based principles for restoring river ecosystems. Bioscience 60 (3), 209-222.

Bednarek, A.T., 2001. Undamming Rivers: A review of the ecological impacts of dam removal. Environ. Manag. 27 (6), 803-814. 
Bieri, M., Muller, M., Boillat, J.L., Schleiss, A.J., 2012. Modeling of sediment management for the Lavey run-of-river HPP in Switzerland. Journal of Hydraulic Engineering 138 (4), 340-347.

Bizzi, S., Dinh, Q., Bernardi, D., Denaro, S., Schippa, L., Soncini-Sessa, R., 2015. On the control of riverbed incision induced by run-of-river power plant. Water Resour. Res. 51, 5023-5040.

Blott, S.J., Pye, K., 2001. GRADISTAT: A grain size distribution and statistics package for the analysis of unconsolidated sediments. Earth Surf. Process. Landforms 26, 1237-1248.

Brandt, S.A., 2000. Classification of geomorphological effects downstream of dams. Catena 40, 375401.

Brasington, J., Langham, J., Rumsby, B., 2003. Monitoring and modelling morphological change in a braided gravel-bed river using high resolution GPS-based survey. Earth Surf. Process. Landforms 25, 973-990.

Bravard, J.P., 1987. Le Rhône, du Léman à Lyon. La Manufacture, Lyon.

Bravard, J.P., 2002. Les réponses des systèmes fluviaux à une réduction des flux d'eau et de sédiments sous l'effet du reboisement en montagne. La Houille Blanche 3, 68-71.

Bravard, J.P., 2010. Discontinuities in braided patterns: The River Rhône from Geneva to the Camargue delta before river training. Geomorphology 117 (3-4), 219-233.

Bravard, J.P., Gaydou, P., 2015. Historical development and integrated management of the Rhône River foodplain, from the Alps to the Camargue delta, France, in: Hudson, P.F., Middelkoop, H. (Eds.), Geomorphic approaches to integrated floodplain management of lowland fluvial systems in North America and Europe. Springer, New York, pp. 289-320.

Bravard, J.P., Landon, N., Peiry, J.L., Piégay, H., 1999b. Principles of engineering geomorphology for managing channel erosion and bedload transport, examples from French rivers. Geomorphology 31, 291-311.

Bravard, J.P., Peiry, J.L., 1993. La disparition du tressage fluvial dans les Alpes françaises sous l'effet de l'aménagement des cours d'eau (19-20ème siècle). Z. Geomorphol., Suppl.-Bd. 88, 67-79.

Camenen, B., Holubová, K., Lukac, M., Le Coz, J., Paquier, A., 2011. Assessment of methods used in 1D models for computing bed-load transport in a large river: the Danube River in Slovakia. J. Hydraulic Eng., 137, 1190-1199.

Camenen, B., Naudet, G., Dramais, G., Paquier, A., \& Le Coz, J., 2018. Evaluation of the sand dynamics at the Isère-Rhône confluence, France. Sci. Total Environ., this issue.

Cœur, D., 2017. Etude historique des prélèvements de sédiments dans le Rhône, 1954-2010. Report + annexes.

Cortier, B., Couvert, B., 2001. Causes et conséquences du blocage actuel de la dynamique fluviale et du transit sédimentaire du Rhône. La Houille Blanche 8, 72-78.

Costigan, K.H., Ruffing, C.M., Perkin, J.S., Daniels, M.D., 2016. Rapid response of a sand-dominated river to installation and removal of a temporary run-of-the-river dam. River Res. Applic. 32, $110-124$. 
Csiki, S., Rhoads, B.L., 2010. Hydraulic and geomorphological effects of run-of-river dams. Progr. Phys. Geogr. 34 (6), 755-780.

Csiki, S., Rhoads, B.L., 2014. Influence of four run-of-river dams on channel morphology and sediment characteristics in Illinois, USA. Geomorphology 206, 215-229.

Curtis, K.E., Renshaw, C.E., Magilligan, F.J., Dade, W.B., 2010. Temporal and spatial scales of geomorphic adjustments to reduced competency following flow regulation in bedloaddominated systems. Geomorphology 118, 105-117.

Dade, W.B., Renshaw, C.E., Magilligan, F.J., 2011. Sediment transport constraints on river response to regulation. Geomorphology 126, 245-251.

Dépret, T., Piégay, H., Dugué, V., Noirot, B., Faure, J.B., Le Coz, J., Camenen, B., Cassel, M., Bultingaire, L., Yousefi, S., Michel K., 2018. Mesures et modélisations du fonctionnement hydrosédimentaire du secteur de Bourg-lès-Valence - Final synthesis report, OSR4.

Dessaix, J., Fruget, J.F., Olivier, J.M., Beffy, J.L., 1995. Changes of the macroinvertebrate communities in the dammed and by-passed sections of the French upper Rhône after regulation. River Res. Applic. 10, 265-279.

Dugué, V., Walter, C., Andries, E., Launay, M., Le Coz, J., Camenen, B., Faure, J.-B. 2015. Accounting for hydropower schemes' operation rules in the 1D hydrodynamic modeling of the Rhône River from lake Genova to the Mediterranean sea. Proceedings (E-proceedings), 36th IAHR Congress, 28 June - 3 July, The Hague, The Netherlands. 9 p.

Fencl, J.S., Mather, M.E., Costigan, K.H., Daniels, M.D., 2015. How big of an effect do small dams have? Using geomorphological footprints to quantify spatial impact of low-head dams and identify patterns of across-dam Variation. PLoS ONE, 10(11): e0141210. doi:10.1371/journal.pone.0141210.

Gaeuman, D. 2012. Mitigating downstream effects of dams, in: Church, M., Biron, P., Roy, AG. (Eds.), Gravel-bed rivers: Processes, tools, environments. John Wiley \& Sons, Chichester, pp. 182-189.

Gaeuman, D., 2014. High-flow gravel injection for constructing designed in-channel features. River Res. Applic. 30, 685-706.

Graf, W.L., 2006. Downstream hydrologic and geomorphic effects of large dams on American rivers. Geomorphology 79, 336-360.

Grant, G.E., 2012. The Geomorphic response of gravel-bed rivers to dams: Perspectives and prospect, in: Church, M., Biron, P., Roy, AG. (Eds.), Gravel-bed rivers: Processes, tools, environments. John Wiley \& Sons, Chichester, pp. 165-181.

Guertault, L., Camenen, B., Peteuil, C., Paquier, A., 2014. Long term evolution of a dam reservoir subjected to regular flushing events. Adv. in Geosci. 39, 89-94.

Ibisate, A., Diaz, E., Ollero, A., Acin, V., 2013. Channel response to multiple damming in a meandering river, middle and lower Aragon River (Spain). Hydrobiologia 712, 5-23. 
Institution interdépartementale des bassins Rhône-Saône, 2003. Etude globale pour une stratégie de réduction des risques dus aux crues du Rhône : 1998-2003.

Isaac, N., Eldho, T.I., 2016. Sediment management studies of a run-of-the river hydroelectric project using numerical and physical model simulations. Intern. J. River Basin Manag. 14 (2), 165-175.

Jones, J.I., Murphy, J.F., Collins, A.L., Sear, D.A., Naden, P.S., Armitage, P.D., 2012. The impact of fine sediment on macro-invertebrates. River Res. Applic. 1055-1071.

Kibler, K.M., Tullos, D.D., Kondolf, G.M., 2011. Learning from dam removal monitoring: Challenges to selecting experimental design and establishing significance of outcomes. River Res. Applic. 27, 967-975.

Kibler, K.M., Tullos, D.D., 2013. Cumulative biophysical impact of small and large hydropower development in Nu River, China. Water Resour. Res. 49, 3104-3118, doi:10.1002/wrcr.20243.

Kondolf, G.M., Gao, Y., Annandale, G.W., Morris, G.L., Jiang, E., Zhang, J., Cao, Y., Carling, P., FU, K., Guo, Q., Hotchkiss, R., Peteuil, C., Sumi, T., Wang, H.W., Wang, Z., Wei, Z., Wu, B., Wu, C., Yang, C.T., 2014. Sustainable sediment management in reservoirs and regulated rivers: Experiences from five continents, Earth's Future 2, 256-280, doi:10.1002/2013EF000184.

Kostic, S., Parker, G., 2003. Progradational sand-mud deltas in lakes and reservoirs. Part 1. Theory and numerical modeling. J. Hydraul. Res. 41 (2), 127-140.

Lajczak, A., 1996. Modelling the long-term course of non-flushed reservoir sedimentation and estimating the life of dams. Earth Surf. Process. Landforms 21, 1091-1107.

Lefort, P., Chapuis, M., 2012. Incidence des aménagements hydro-électriques sur la morphologie des tronçons court-circuités de la Durance et du Verdon. La Houille Blanche 2, 42-48

Liébault, F., Clément, P., Piégay, H., Landon, N., 1999. Assessment of bedload delivery from tributaries: The Drôme River case, France. Arct., Antarct., Alp. Res. 31 (1), 108-117.

Liébault, F., Clément, P., Piégay, H., Rogers, C.F., Kondolf, G.M., Landon, N., 2002. Contemporary channel changes in the Eygues basin, southern French Prealps: the relationship of subbasin variability to watershed characteristics. Geomorphology 45 (1-2), 53-66.

Liébault, F., Piégay, H., 2002. Causes of 20th century channel narrowing in moutain and piedmont rivers of southeastern France. Earth Surf. Process. Landforms 27, 425-444.

Lobrera, G., Munoz, I., Lopez-Tarazon, J.A., Verciat, D., Batalla, R.J., 2016. Effects of flow regulation on river bed dynamics and invertebrate communities in a Mediterranean river. Hydrobiologia 784 (1), 283-304.

Magilligan, F.J., Graber, B.E., Nislow, K.H., Chipman, J.W., Sneddon, C.S., Fox, C.A., 2016. River restoration by dam removal: Enhancing connectivity at watershed scales. Elementa: Science of the Anthropocene 4, 000108, doi: 10.12952/journal.elementa.000108.

Malavoi, J.R., Garnier, C.C., Landon, N., Recking, A., Baran, P., 2011. Eléments de connaissance pour la gestion du transport solide en rivière. ONEMA, $215 \mathrm{pp}$. 
McManamay, R.A., Oigbokie, C.O., Kao, S.C., Bevelhimer, M.S., 2016. Classification of US hydropower dams by their modes of operation. River Res. Applic. 32, 1450-1468.

Meyer-Peter, E., Müller, R., 1948. Formulas for bed load transport. Proceedings, 3rd Meeting of International Association Hydraulic Resources, Stockholm, pp. 39-64.

Morris, GL., Annandale, G., Hotchkiss, R., 2008. Reservoir Sedimentation, in: Garcia, M. (Eds.), Sedimentation engineering: Processes, measurements, modeling, and practice. American Society of Civil Engineers Manual 110, pp. 579-612.

Morris, G.L., Fan, J., 1998. Reservoir sedimentation handbook: Design and management of dams, reservoirs, and watersheds for sustainable use. McGraw-Hill Book Co., New York.

Nilsson, C., Berggren, K., 2000. Alterations of Riparian Ecosystems Caused by River Regulation. BioScience 50 (9), 783-792.

Olivier, J. M., Carrel, G., Lamouroux, N., Dole-Olivier, M.J., Malard, F., Bravard, J.P. Amoros, C., 2009. The Rhône river basin. In: Robinson, C., Uehlinger, U., Tockner, K. (Eds.), Rivers of Europe. Elsevier, San Diego, pp. 247-295.

Parrot, E., 2015. Analyse spatio-temporelle de la morphologie du chenal du Rhône du Léman à la Méditerranée. Ph.D. Thesis, Lyon 3 University.

Pearson, A.J., Pizzuto, J., 2015. Bedload transport over run-of-river dams, Delaware, U.S.A. Geomorphology 248, 382-395.

Petts, G.P., Gurnell, A.M., 2005. Dams and geomorphology: Research progress and future directions. Geomorphology 71, 27-47.

Petts, G.P., Gurnell, A. 2013. Hydrogeomorphic effects of reservoirs, dams, and diversions, in: Shroder J. (Editor in Chief), Wohl, E. (Eds.), Treatise on Geomorphology. Academic Press, San Diego CA. Vol. 13, Fluvial Geomorphology, pp. 96-113.

Poff, N.L., 2017. Beyond the natural flow regime? Broadening the hydro-ecological foundation to meet environmental flows challenges in a non-stationary world. Freshwater Biology, doi: 10.1111/fwb.13038.

Poff, N.L., Tharme, R.E., Arthington, A.H., 2017. Evolution of environmental flows assessment science, principles, and methodologies, in: Horne, A.C., Webb, J.A., Stewardson, M.J., Richter, B., Acreman, M. (Eds.), Water for the environment, from policy and science to implementation and management. Academic Press, pp. 203-236.

Poff, N.L., Zimmerman, J.K.H., 2010. Ecological responses to altered flow regimes: a literature review to inform the science and management of environmental flows. Freshwater Biology 55, 194-205.

Poinsart, D., 1992. Effets des aménagements fluviaux sur les débits liquides et solides. L'exemple du Rhône dans les plaines de Miribel-Jonage et Donzère-Mondragon. Ph.D. Thesis, Lyon 3 University. 
Poinsart, D., Salvador, P.G., 1993. Histoire de l'endiguement du Rhône à l'aval de Lyon (XIXe siècle). Actes du colloques "Le fleuve et ses métamorphoses", Lyon, France, 13-15 mai 1992, pp. 299-313.

Rheinheimer D.E., Yarnell, S.M., 2017. Tools for sediment management in rivers, in: Horne, A.C., Webb, J.A., Stewardson, M.J., Richter, B., Acreman, M. (Eds.), Water for the environment, from policy and science to implementation and management. Academic Press, pp. 237-263.

Rollet, A.J., Piégay, H., Dufour, S., Bornette, G., Persat, H., 2013. Assessment of consequences of sediment deficit on a gravel river bed downstream of dams in restoration perspectives: Application of multicriteria, hierarchical and spatially explicit diagnosis. River Res. Applic. 30 (8), 939-953.

Rolls, R.J., Bond, N.R., 2017. Environmental and ecological effects of flow alteration in surface Water ecosystems, in: Horne, A.C., Webb, J.A., Stewardson, M.J., Richter, B., Acreman, M. (Eds.), Water for the environment, from policy and science to implementation and management. Academic Press, pp. 237-263.

Rosenberg, D.M., McCully, P., Pringle, C.M., 2000. Global-scale environmental effects of hydrological alterations: Introduction. Bioscience 50 (9), 746-751.

Schmidt, J.C., Wilcock, P.R., 2008. Metrics for assessing the downstream effects of dams. Water Resour. Res. 44, W04404, doi:10.1029/2006WR005092.

Sindelar, C., Schobesberger, J., Habersack, H., 2017. Effects of weir height and reservoir widening on sediment continuity at run-of-river hydropower plants in gravel bed rivers. Geomorphology 91 , 106-115.

Snyder, N.P., Rubin, D.M., Alpers, C.N., Childs, J.R., Curtis, J.A., Flint, L.E., Wright, S.A., 2004. Estimating accumulation rates and physical properties of sediment behind a dam: Englebright Lake, Yuba River, northern California. Water Resour. Res. 40, W11301, doi:10.1029/2004WR003279.

Stroffek, S., Amoros, C., Zylberblat, M., 1996. La logique de réhabilitation physique appliquée à un grand fleuve : le Rhône. Géocarrefour 71 (4), 287-296.

Vazquez-Tarrio, D., Tal, M., Camenen, B., Piégay, H., 2018. Present-day bed load transport capacities along the Rhône River following a century and half of human modifications. Sci. Total Environ., this issue.

Warner, R.F., 2000. Gross channel changes along the Durance River, Southern France, over the last 100 years using cartographic data. River Res. Applic. 16, 141-157.

Williams, G.P., Wolman, M.G., 1984. Downstream effects of dams on alluvial rivers. United States Geological Survey Professional Paper 1286.

Yarnell, S.M., Mount, J.F., Larsen, E.W., 2006. The influence of relative sediment supply on riverine habitat heterogeneity. Geomorphology 80, 310-324. 